PROBLEMS

OF EDUCATION

IN THE $21^{\text {st }}$ CENTURY

Vol. 76, No. 1, 2018

${ }^{58}$ THE LEVEL OF PHYSICAL ACTIVITY

OF CHILDREN IN KINDERGARTEN IN THE LIGHT OF SELECTED INDIVIDUAL FACTORS

\author{
Stanisława Nazaruk, Joanna Waszczuk, \\ Joanna Marchel, Helena Kowaluk-Nikitin \\ Pope John Paul II State School of Higher Education in Biała Podlaska, Poland \\ E-mail: stnazaruk@poczta.onet.pl, awaszczuk@op.pl, \\ joanna44@o2.pl, konowaluk@gmail.com \\ Anna Klim-Klimaszewska \\ University of Natural Sciences and Humanities in Siedlce, Poland \\ E-mail: klimanius@interia.pl
}

\begin{abstract}
Taking into account the psychophysical development of a young person, a child in particular, attention should be paid to forming certain habits related to physical activity, health, nutrition, hygiene, and aesthetics during the preschool period as such habits will be of utmost importance in his/ her adult life. Physical activity of children affects various health parameters both today and in the future. Specialists draw attention to the correlation between physical activity and the development of the musculoskeletal system, body posture, the nervous, respiratory and vegetative systems. The lack of physical activity may result in cardiovascular diseases or obesity. These are just some of the reasons for which people need physical activity in their lives. Bearing in mind the lack of research on this issue, it was decided to conduct research on the physical activity of children (210 students) aged 4-6 attending selected kindergartens located in the town of Biata Podlaska, Poland. The level of physical activity of children was measured with the use of special devices, so called actigraph units (accelerometers in Polish). Due to a small size of this wrist-watch-like device, movements of children or their participation in games and different forms of activities in kindergarten were not hampered. On the basis of the collected data, statistical analysis was performed. Non-parametric statistical tests were used in order to identify the relationship between variables of the physical activity level and sex, age and weight of a child. Data analysis revealed statistically significant differences between the level of physical activity and some personal characteristics. The research conclusions, which will be helpful in providing effective education in the field of physical activity, were made available to kindergartens.
\end{abstract}

Keywords: actigraph, accelerometer, kindergarten, pre-school child, physical activity.

\title{
Introduction
}

Nowadays the conviction about the need for physical activity as a permanent and necessary factor to maintain health is deepening. Among the ranking of factors that maintain and multiply health, it occupies a priority place. It is an indispensable element affecting the health and well-being of people. At this point, it should be noted that there are many definitions of physical activity in which different elements of this problem are noticed and its multidimensional character is emphasized (Barankiewicz, 1998; Drabik, 201; Bielski, 2005). Józef Drabik believes that "physical activity is a key and integral component of a healthy 
lifestyle. Without it, no strategy of health, its maintenance and multiplication is possible, and in children - proper development " (Drabik, 2001, p. 5).

Since during millennia of the evolution of the human race, physical activity was a necessary condition for survival, it became a part of human nature. Therefore, the appropriate level of physical activity of modern man not only favours the functions and development of the body, but also has a positive effect on the psyche and well-being (Pawłucki, 1996).

Lack of regular physical exercise is the cause of the development of many chronic diseases, what is more, the detailed results of epidemiological and clinical studies prove that these diseases are more common in people who take physical activity to a small extent or do not take it at all. Hypokinesis (lack of movement or its insufficient dose) is considered even as one of the sources of the obesity epidemic (Cordero-MacIntyre, Peterson, Fukuda, Gungur, 2006) and the accompanying metabolic syndrome (Bloomgarden, 2004), it is also considered one of the causes of ischemic heart disease (Janssen, 2007) and cancers (Mao, Wen, Johnson, 2003).

In contrast to hypokinesia, the appropriate dose of physical activity brings many health benefits (Bruunsgaard, 2005), among others it improves the efficiency of the cardiovascular and respiratory system (Watts, Beye, Siafarikas, O'Driscoll, Jones, Davis, Green, 2004) and delays the appearance of symptoms of these diseases (Schnohr, Lange, Scharling, Jensen, 2006). The life capacity of the lungs, breathing depth and oxygen consumption are also increased, and the number of breaths per minute and the amount of oxygen debt are reduced. In addition, strong respiratory muscles shape the chest, causing it to grow and improve the body posture, which improves the supply of oxygen to the body.

Movement is used successfully everywhere where development deviations can be eliminated or mitigated through appropriate exercises and in the therapy of many developmental disorders and diseases (Bielski, 2005; Pawłucki 1996). The research confirmed the unique importance of physical activity in the prevention of civilization diseases and proved its affiliation to the main determinants of the human health field (Cendrowski, 2002).

It should be noted that "physical health is not the only benefit of physical activity, but also the significant value associated with emotional experiences shaped in the common play, game, dance, singing, etc." (Cendrowski, 2002, p. 11).

In the broad context of health and emotional factors, the importance of physical activity in learning process was appreciated. Researchers have proven that about $50 \%$ of learning abilities develop up to the fourth year of life, and further $30 \%$ before the end of the eighth year (Woynarowska, Kowalewska, Izdebski, Komosińska, 2010; Wolański, 2012). During this period, the main nerve pathways are created, enabling lifelong learning. They will continue to form, but the foundations are shaped in the years mentioned. Children, through regular exercises, greatly support brain development. This is because the so-called atrial system is stimulated. Physical exercises stimulate the maturation of the motor centres in the brain, which improves the development of motor fitness. The speed of conduction of nerve stimuli increases, coordination of movements is improved (Osiński, 2003; Wolański, 2012).

As mentioned before, the importance of physical activity in human development is particularly important in the pre-school period (3-6 years), when the child grows, develops, learns behaviours, assimilates norms, values and shapes habits. To develop the child's physical activity in a professional way obliges the Program of Pre-school Education (Journal of Laws of 24 February 2017, Item 356). The said document contains provisions obligating kindergartens to create conditions and implement in practice all the activities of children, including physical ones, among others developing motor skills in the field of large and small motor skills that will be necessary in school education.

Due to the fact that in Poland there are almost 90\% of children aged 3-6 in pre-school education, the importance of the work of these institutions in the area of physical activity seems to be leading. Bearing in mind the concern for the proper development of a child and taking into account the fact that there are no studies on the level of physical activity of pre-school children, it should be assumed that there is a need for this type of research. 
Stanisława NAZARUK, Joanna WASZCZUK, Joanna MARCHEL, Helena KOWALUK-NIKITIN, Anna KLIM-KLIMASZEWSKA. The level of physical activity of children in kindergarten in the light of selected individual factors

IN THE $21^{\text {st }}$ CENTURY Vol. 76, No. 1, 2018

60

The main purpose of the research was to identify the actual level of physical activity of children during their stay in kindergarten. The following research problems were formulated with regard to the research purpose:

1. What physical activity level do 4 to 6-year-old children demonstrate during educational classes in kindergarten in one day?

2. Does the physical activity level of children depend on their sex or age?

3. Is weight and height (Body Mass Index) of significance in undertaking physical activity by children?

\section{Methodology of the Research}

\section{General Background}

The conducted research is a part of the research on physical activity of pre-school children. Taking into account the presented problems, the research was carried out in Poland in three local kindergartens in city Biała Podlaska. Children who had a written consent from their parents or legal guardians joined the tests. Measurements of the level of physical activity of children were made using special devices, so-called actigraphs (MTI7164), which determined the objectivity and accuracy of the test results.

\section{Procedure and Data Collection}

The research was performed from the $4^{\text {th }}$ to the $30^{\text {th }}$ of September 2017 . Before its start, each child's weight and height were measured. The collected data: sex, age, weight and height were recorded in the computer programme. Every day of testing, an actigraph unit was worn on the wrist by children starting at $8.30 \mathrm{a} . \mathrm{m}$. Due to a small size of the device, it did not interfere with normal activity of children, e.g. jumping or running. Actigraph units were removed at 3.00 p.m. when kindergarten classes were over. There were 20 devices available to measure physical activity of children, so 20 children were tested at the same time in one day. The data from actigraph units were entered into the computer system every day after the completion of testing in kindergarten. The research was conducted for the period of twenty-one days in September 2017.

\section{Data Analysis}

Statistical analysis of the obtained data was performed in the STATISTICA v. 10. program. For the examined characteristics defining the level of physical activity of children, arithmetic means were calculated. In order to detect statistically significant differences, nonparametric U Mann-Whitney test and Krsukal-Wallis tests were used. In all analysed cases, the significance level was assumed $\mathrm{p}=.05$.

\section{Participants}

The research included children aged 4 to 6 , attending three kindergartens in Biała Podlaska, i.e. Self-Government Kindergartens No. 14, No. 10 and No. 6. The body running the mentioned facilities is the Self-Government of Biała Podlaska. The basic data of the studied group of children are presented in Table 1. 
Stanisława NAZARUK, Joanna WASZCZUK, Joanna MARCHEL, Helena KOWALUK-NIKITIN, Anna KLIM-KLIMASZEWSKA. The level of physical activity of children in kindergarten in the light of selected individual factors

PROBLEMS

OF EDUCATION

IN THE $21^{\text {st }}$ CENTURY

Table 1. Basic information data concerning children participating in the research Vol. 76 , No. 1, 2018 $(\mathrm{N}=\mathbf{2 1 0})$.

\begin{tabular}{lll}
\hline Variable & Number of children & Structure (\%) \\
\hline Sex & & \\
\hline Girls & 93 & 54.29 \\
\hline Boys & 117 & 55.71 \\
\hline Age & 21 & 10.00 \\
\hline 4 years old & 98 & 46.67 \\
\hline 5 years old & 91 & 43.33 \\
\hline 6 years old & & 42.65 \\
\hline BMl - Body Mass Index & 90 & 51.47 \\
\hline Thinness & 108 & 5.88 \\
\hline Normal weight & 12 & \\
\hline Overweight & & \\
\hline
\end{tabular}

210 children participated in the research, $55.71 \%$ of which were boys, and $44.29 \%$ were girls. The smallest group were 4-year-old children, while groups of 5- and 6-year-old children were comparable.

\section{Results of Research}

Three levels of intensity of physical activity were determined using activity measuring devices. These are levels of moderate, low and sedative intensity (also known as sedentary). Due to the psychophysical correctness of a child development, physical activity with moderate intensity is the most beneficial.

Detailed results of the children's examinations, which determine the levels of physical activity are as follows:

1) high activity level $-0 \%$ of children

2) moderate activity level $-43.8 \%$ of children;

3) low activity level $-49.7 \%$ of children;

4) below-low activity level, referred to as sedative mode $-6.5 \%$ of children.

Regarding these results, it should be noted that physical activity at a moderate level was recorded only in approximately $43.8 \%$ of the studied population. Thus, the results of over $50 \%$ of the examined children are unsatisfactory, which may in the future lead to the consolidation of bad habits, overweight, faulty posture or other developmental constraints.

The results of the intensity of physical activity of children, including gender, are shown in Figure 1. 
Stanisława NAZARUK, Joanna WASZCZUK, Joanna MARCHEL, Helena KOWALUK-NIKITIN, Anna KLIM-KLIMASZEWSKA. The level of physical activity of children in kindergarten in the light of selected individual factors

OF EDUCATION

IN THE $21^{\text {st }}$ CENTURY Vol. 76, No. 1, 2018

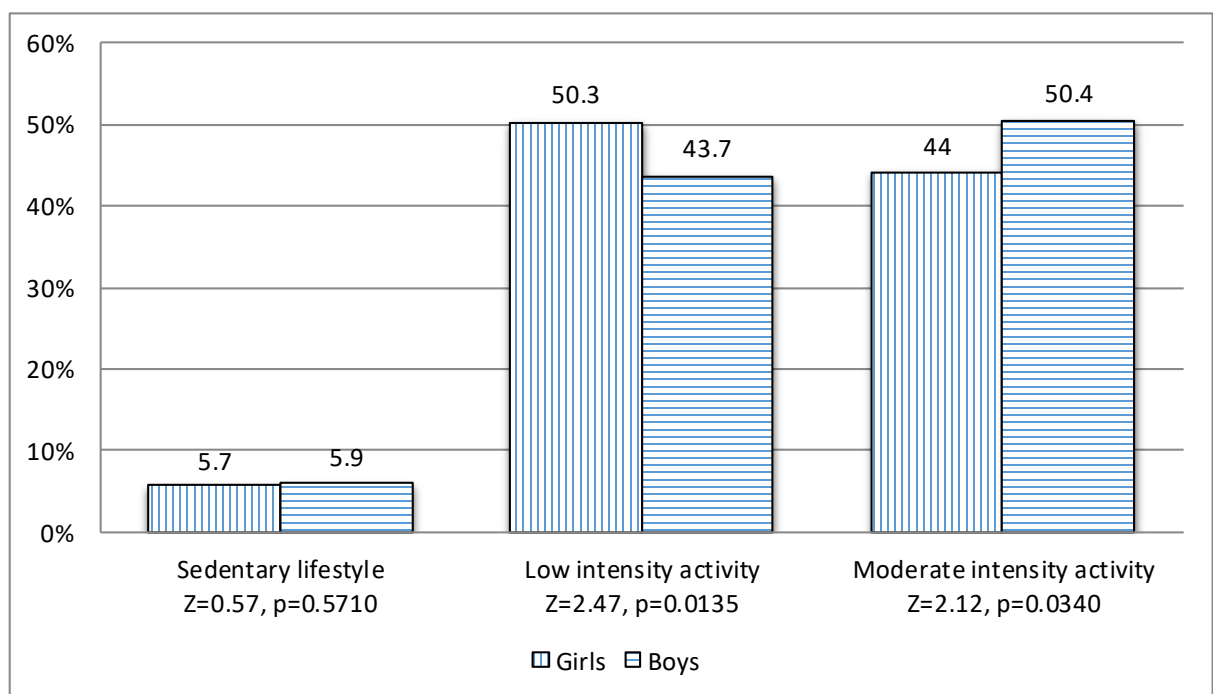

Figure 1: Intensity of physical activity of the examined children, including sex. Z-value of the Mann-Whitney $\mathrm{U}$ test.

The data presented in Figure 1 show that boys are more physically active compared to girls. On a moderate level, they achieved better results. In turn, the girls' results are slightly higher at the low level compared to the boys indicate their lower activity. The collected data allow to suppose that boys prefer movement activities, such as games, running, ball games and accessories. However, girls prefer classes at tables such as painting, drawing, writing, listening, singing, playing with dolls, playing home or resting. Based on the calculated values of the Mann-Whitney $U$ test and the assumed significance level of $p=0.05$, it should be stated that the observed differences between the sexes at two levels of physical activity, namely a moderate and a low one, are statistically significant.

Figure 2 shows the results in terms of the intensity of physical activity of the examined group of children depending on their age.

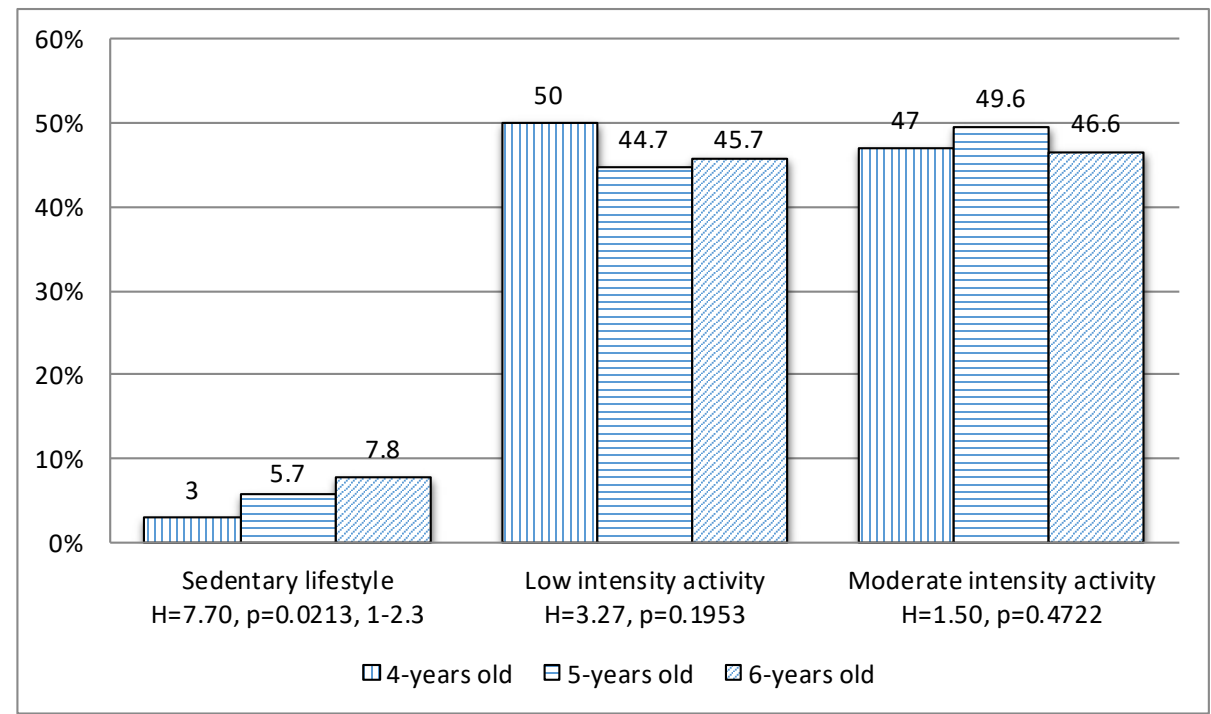

Figure 2: Intensity of physical activity of the examined children, taking into account their age.

$\mathrm{H}$-value of the Kruskal-Wallis test. 
Stanisława NAZARUK, Joanna WASZCZUK, Joanna MARCHEL, Helena KOWALUK-NIKITIN, Anna KLIM-KLIMASZEWSKA. The level of physical activity of children in kindergarten in the light of selected individual factors

\author{
PROBLEMS \\ OF EDUCATION \\ IN THE $21^{\text {st }}$ CENTURY \\ Vol. 76, No. 1,2018
}

The obtained data shows that 5-year-old children show the highest physical activity in kindergarten in comparison with 6-year-old and 4-year-old children. However, these are not statistically significant differences. Based on the calculated values of the Kruskal-Wallis test and the adopted level of significance, $p=0.05$ it is stated that there is no significant statistical differentiation in the physical activity of children depending on their age at a moderate and low level. Statistically significant differences were observed at a sedentary level.

Figure 3 illustrates the intensity of physical activity of the examined group of children depending on their BMI.

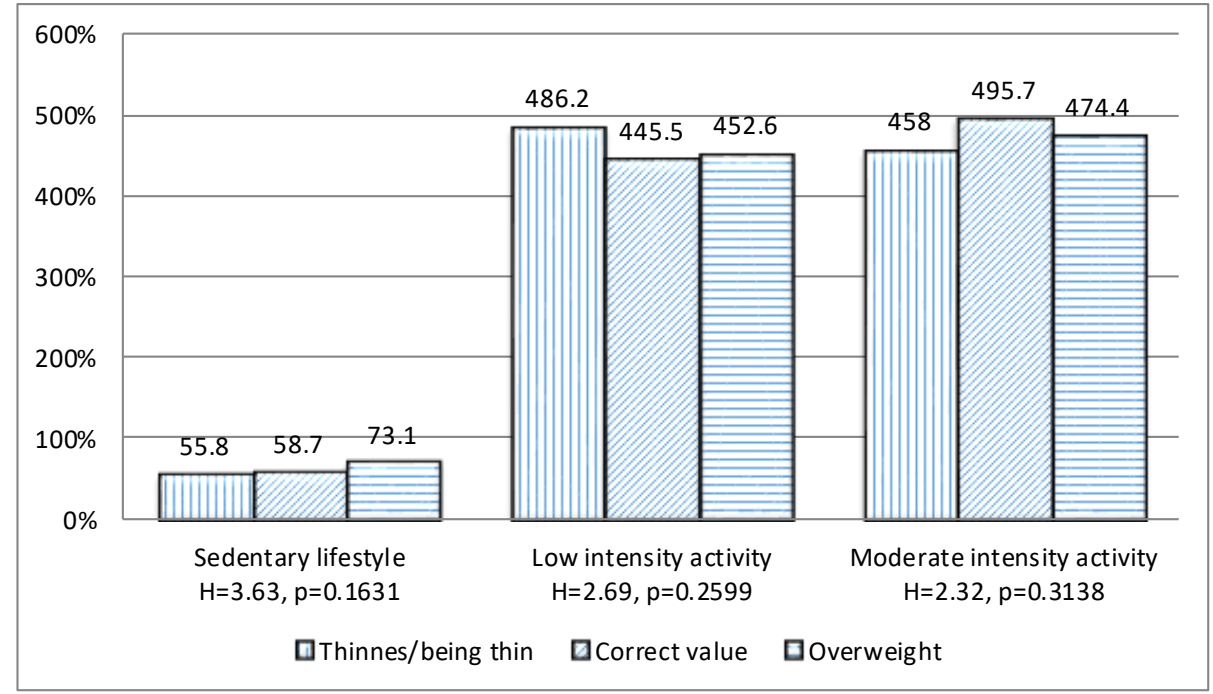

\title{
Figure 3: Intensity of physical activity of the examined children taking into account their BMI.
}

$\mathrm{H}$ - value of the Kruskal-Wallis test.

On the basis of the calculated value of the Kruskal-Wallis test and the adopted level of significance $\mathrm{p}=.05$, it can be stated that there is no significant statistical differentiation in the physical activity of children depending on their BMI.

Physical activity of children was determined using the Steps Per Minute test in which the number of steps taken by a child in one minute is counted. Figure 4 illustrates the results of the Steps Per Minute test taking into consideration children's sex and age. 
Stanisława NAZARUK, Joanna WASZCZUK, Joanna MARCHEL, Helena KOWALUK-NIKITIN, Anna KLIM-KLIMASZEWSKA. The level of physical activity of children in kindergarten in the light of selected individual factors

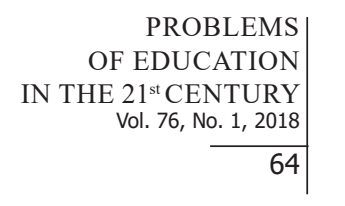

PROBLEMS

$21^{\text {st }}$ CENTURY

64

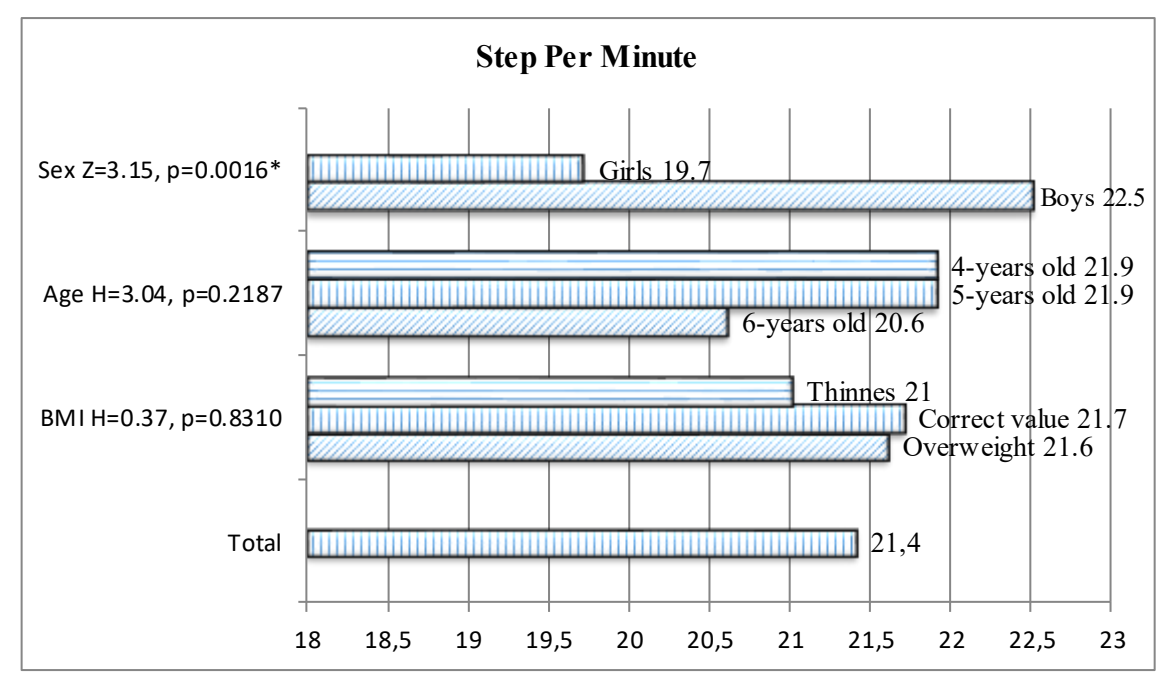

Figure 4: The number of steps per minute performed by children, including gender and age.

$\mathrm{Z}$ - value of the Mann-Whitney $\mathrm{U}$ test, $\mathrm{H}$-value of Kruskal-Wallis test, * significant variation at $p=.05$.

The data presented in Figure 4 shows that the best score from the Steps Per Minute test was achieved by boys. The results of the U Mann-Whitney and Kruskal-Wallis test at the significance level of $\mathrm{p}=.05$ allow to conclude that there is a significant statistical differentiation of results depending on the sex. However, the results of the children's test with regard to age are very similar. Small differences were found which, using statistical tests, did not confirm their significance.

Summing up the results of the conducted research stated that in all age it should also be groups, boys showed greater physical activity than girls. The biggest difference between girls and boys was found in the group of 6-year-old children, the smallest in the group of 4-year-old children, although it was slightly smaller than the difference between girls and boys in the group of 5-year-old children.

\section{Discussion}

The aim of the undertaken research was to learn the level of physical activity of children aged 4-6 during educational and upbringing activities in kindergarten in one day. The mentioned goal was implemented in several selected kindergartens in Biała Podlaska. The mentioned facilities have similar housing conditions, are run by Self-Government, they implement the core curriculum of pre-school education and a similar plan of work with children during the day. The aforementioned similarities are the basis for stating that children in kindergartens in Biała Podlaska have similar conditions to develop physical activity. Therefore, it can be assumed, considering the developmental age of a child (4-6 years), which is characterized by a strong need for movement, that the level of physical activity manifested by children in kindergarten should be similar and at the correct level. It should be emphasized once again that all kindergartens are obliged to implement the guidelines contained in the Program of Preschool Education, in which the Ministry of National Education indicated the skills that a child should achieve after reaching the age of 6 , including physical fitness skills, which is among others, the element of child's achievement of school readiness. The mentioned document does not give ready solutions regarding the selection and application of specific methods of work of teachers with children in kindergarten. This issue was left to the teachers' disposal. Teachers 
draw up the kindergarten work plan themselves choosing the forms, methods and techniques of working with children taking into account many factors such as the rate of child's development, the need for movement, interests, predispositions and talents. The results of the research carried out among 210 pre-schoolers revealed that only $47.8 \%$ of children demonstrated physical activity at a moderate level, and $5.8 \%$ of children showed a sedentary level of physical activity. No high activity level was observed.

Considering the biological development of a child of this age, i.e. the development of bone and muscle tissue, maturation of the nervous system, the final stage of innervation of muscle groups, lack of physical activity at an appropriate level may be a limiting factor for a child development in both physical and intellectual dimensions. The relationship between physical activity and child development is undisputed. That is why, more and more specialists in the field of health pay attention to the key importance of the kindergarten in the process of physical activation of children.

European research on physical activity level of children, depending on age, sex or even the kind of kindergarten, comprises the research performed in Denmark, Portugal and Poland. The research in the above-mentioned countries revealed differing levels of physical activity of kindergarten children, even of the same age. Physical activity of children in Denmark was tested using special devices called accelerometers. The research results revealed that about $50 \%$ of 4 to 6-year-old children engaged in a moderate level of activity, and girls were less active in comparison with boys of the same age (Pate et al., 2006). Another research on physical activity of 4 to 6-year-old children during their stay in kindergarten was performed in Porto, Portugal. The research was conducted with the use of accelerometers for the period of 7 consecutive days and examined the relationship between physical activity and obesity of children. The research results indicated that boys were more active and had a lower obesity rate than girls (Vale et al., 2013).

Current research results show an increasing tendency to limit physical effort of people (especially children and adolescents) in favour of mental effort and a static lifestyle (Merkiel, Chalcarz, Deptuła, 2011).

We also observe a tendency of the family's weakening role in shaping physical activity, e.g. after the child's return from kindergarten to home. In the majority of children, they spend time at home in a way that is not very physically active, because more and more often both children and their parents prefer passive leisure activities (Korpak, Bergier, 2013). The results of the research conducted in Sweden on 4-year-old children exemplify this trend. The aim of the research was to compare physical activity of children during five days of their stay in kindergarten with their physical activity at the weekend at home. The research results revealed that physical activity of children during the weekend is lower in comparison with their activity during their stay in kindergarten. Most children spend their leisure time at home with their family in a passive way (Berglind, Tynelius, 2018).

The purpose of the research was to determine the differences in the level of physical activity of children depending on individual factors, mainly gender and age. In Poland, so far, no research has been recorded in the field of physical activity measurement (using actigraphs) of children aged 4-6 during educational and upbringing activities in kindergarten. In the context of the Danish research, the results of research from Polish kindergartens carried out in Biała Podlaska show a similar tendency. At the same time, the physical activity test was extended by an additional Steps Per Minute test. The results of this test showed differences between girls and boys, which turned out to be statistically significant. This allowed to conclude that individual factors, especially sex, significantly affect the physical activity of children aged 4-6. A similar tendency in terms of physical activity was observed in the comparative analysis of physical activity of adolescents from six countries conducted by Józef Bergier and Małgorzata Wasilewska, in which a downward trend in activity was observed depending on sex and age. At the same time, the relationship between activity and cultural factors was pointed out (Wasilewska, Bergier, 2015). There were also reports on the physical activity of school youth depending on

$\mid \begin{aligned} & \text { PROBLEMS } \\ & \text { OF EDUCATION } \\ & \text { IN THE } 21^{\text {st }} \text { CENTURY } \\ & \text { Vol. 76, No. } 1,2018\end{aligned}$ 
Stanisława NAZARUK, Joanna WASZCZUK, Joanna MARCHEL, Helena KOWALUK-NIKITIN, Anna KLIM-KLIMASZEWSKA. The level of physical activity of children in kindergarten in the light of selected individual factors

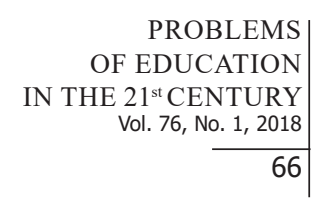

66

the type of place of residence carried out with the help of the International Physical Activity Questionnaire IPAQ. Schoolchildren, especially boys living in family homes, are characterized by a higher level of physical activity than their peers living in blocks (Bergier, Niznikowska, Bergier, Junger, Salonna, 2016). Examination of the physical activity of kindergarten children depending on their family environment and living conditions will probably be another objective of the research, which is going to be continued because of its importance to the health of children.

\section{Conclusions}

On the basis of an analysis of the collected empirical data, the research conclusions were drawn, which would be helpful in organising effective educational work in kindergartens in the field of physical activity. Unfortunately, the level of physical activity of more than $50 \%$ of children during one day of their stay in kindergarten, which was measured objectively with the use of actigraph units, is a disadvantage for normal development, and may result in decreased mobility, faulty postures or even obesity in the future. These are just some of the negative consequences of the lack of optimal amount of physical activity in child development.

Therefore, it has been recommended that kindergartens, being the major institution organising physical activity for children aged 4-6, should modify their educational work and introduce various forms and methods of physical activity in order to encourage children to engage in it. Bearing in mind the research results indicating lower physical activity of girls in comparison with boys, it has been recommended that teachers should individualise their actions. Such approach is particularly advisable in the case of a group of students who need support, not only girls but all children whose physical activity level was identified as sedentary.

On the basis of the research findings it can also be concluded that parents should spend their free time with children in an active way. Children's active participation in leisure activities may form pro-health habits in their future adult lives. The conducted research showed that there is still a need to perform further research and have a further discussion on physical activity of children because the brain and body systems are developed in the kindergarten period. Moreover, in the same period children shape their habits and acquire values, to which health certainly belongs. Thus, bearing in mind the importance of the presented problem of physical activity of children, it should be stated that this issue will be the subject of further research.

\section{References}

Barankiewicz, J. (1998). Leksykon wychowania fizycznego i sportu szkolnego [Leksykon of physical education and school sport]. Warszawa: WSiP.

Bergier, J., Niznikowska, E., Bergier, B., Junger, J. Acs., \& Salonna, F. (2016). Diversity of physical activity among the school youth. Health Problems of Civilization, 10 (1), 24-31. doi:10.5114 / hpc.2016.58205.

Berglind, D., \& Tynelius, P. (2018). Objectively measured physical activity patterns, sedentary time and parentreported screen-time across the day in four-year-old Swedish children. BMC Public Health, 18, 69. doi:10.1186/s12889-017-4600-5.

Bielski, J. (2005). Metodyka wychowania fizycznego i zdrowotnego - podręcznik dla nauczycieli wychowania fizycznego [Methodology of physical and health education - textbook for teachers physical education]. Krakow: Impuls, p. 166.

Bloomgarden, Z. T. (2004). Type 2 diabetes in the young. Diabetes Care, 27 (5), 998-1010.

Bruunsgaard, H. (2005). Physical activity and modulation of systemic low-level inflammation. Journal of Leukocyte Biology, 78, 1-17. doi:10.1189/jlb.0205074.

Cendrowski, Z. (2002). Aktywność fizyczna dzieci i młodzieży [Physical activity of children and adolescents]. LIDER, 2, 11-12. 
Stanisława NAZARUK, Joanna WASZCZUK, Joanna MARCHEL, Helena KOWALUK-NIKITIN, Anna KLIM-KLIMASZEWSKA. The level of physical activity of children in kindergarten in the light of selected individual factors

Cordero-MacIntyre, Z., Peterson, R., Fukuda, D., \& Gungur, S. (2006). Obesity a worldwide problem. In: Czyz S, \& Viviani F. (Eds.), New Horizons.24th International Council for Physical Activity and Fitness Research Symposium. Wrocław: Elsevier Urban \& Partner, p. 61-71.

Drabik, J. (2011). Profilaktyka zdrowia - aktywność fizyczna czy aktywność ruchowa [Prevention of health - physical activity or physical activity]. Physical and Health Education, 5, 5-6.

Janssen, I. (2007). Physical activity, fitness, and cardiac, vascular, and pulmonary morbidities. In: Bouchard C, Blair S. N., \& Haskell W. L. (Eds.), Physical Activity and Health. Champaign, IL: Human Kinetics, p. 161-172.

Korpak, F., \& Bergier, J.(2013). Review of research on physical activity of children and adolescents school in Poland. Man and Health, 07 (1), 78-90.

Mao, Y., Pan, S., Wen, S. W., \& Johnson, K. C. (2003). Physical activity and the risk of lung cancer in Canada. American Journal Epidemiology, 158 (6), 564-575. doi: 10.1093/aje/kwg186.

Merkiel, S., Chalcarz, W., \& Deptuła, M. (2011). Porównanie aktywności fizycznej oraz ulubionych form spędzania czasu wolnego dziewczynek i chłopców w wieku przedszkolnym z województwa mazowieckiego [Comparison of physical activity and favourites forms of spending free time girls and boys of pre-school age from Masovia Province]. Roczniki Państwowego Zakładu Higieny, 62 (1), 93-99.

Osiński, W. (2003). Antropomotoryka [Anthropomotorics]. Poznań: AWF.

Pate, R. R., Almeida, M. J, McIver, K. L., Pfeiffer, K. A., \& Dowda, M. (2006). Validation and calibration of an accelerometer in preschool children. Obesity (Silver Spring), 14 (11), 2000-6.

Pawłucki, A. (1996). Pedagogika wartości ciała [Pedagogy of body values]. Gdańsk: AWF.

Rozporządzenie Ministra Edukacji Narodowej z dnia 14 lutego 2017 r. w sprawie podstawy programowej wychowania predszkolnego oraz podstawy programowej kształcenia ogólnego dla szkoły podstawowej (Dziennik Ustaw z dnia 24 lutego 2017, Poz. 356) [Regulation of the Minister of National Education of 14 February 2017 on the core curriculum of pre-school education and the core curriculum of general education for primary school (Journal of Laws of 24 February 2017, item 356)].

Schnohr, P., Lange, P., Scharling, H., \& Jensen, J. S. (2006). Long-term physical activity in leisure time and mortality from coronary heart disease stroke, respiratory diseases and cancer. The Copenhagen City Heart Study. European Journal Cardiovascular Prevention and Rehabilitation, 13 (6), 173 179.

Wasilewska, M., \& Bergier, J. (2015). Physical activity level in selected countries of the world. Health Problems of Civilization, 3 (9), 39-46.

Watts, K., Beye, P., Siafarikas, A., O'Driscoll, G., Jones, T. W., Davis, E. A., \& Green, D. J. (2004). Effects of exercise training on vascular function in obese children. Journal of Pediatrics, 144 (6), 620-625.

Wolański, N. (2012). Rozwój biologiczny człowieka [The biological development of man]. Warszawa: PWN.

Woynarowska, B., Kowalewska, A., Izdebski, Z., \& Komosińska, K. (2010). Biomedyczne podstawy ksztatcenia $i$ wychowania [Biomedical foundations education and upbringing]. Warszawa: PWN.

Vale, S., Trost, S., Ruiz, J. J., Re`go, C., Moreira, P., \& Mota, J. (2013). Physical activity guidelines and preschooler's obesity status. International Journal of Obesity, 37, 1352-1355. 
Stanisława NAZARUK, Joanna WASZCZUK, Joanna MARCHEL, Helena KOWALUK-NIKITIN, Anna KLIM-KLIMASZEWSKA. The level of physical activity of children in kindergarten in the light of selected individual factors

PROBLEMS

OF EDUCATION

IN THE $21^{\text {st }}$ CENTURY

Vol. 76, No. 1, 2018

Received: December 22, 2017

Accepted: February 22, 2018

\section{Stanisława Katarzyna Nazaruk}

Joanna Waszczuk

Joanna Marchel

Helena Konowaluk-Nikitin

PhD, Pope John Paul II State School of Higher Education in Biala Podlaska, Faculty of Humanities and Social Sciences, Department of Education, ul. Sidorska 95/97, 21-500 Biała Podlaska, Poland. E-mail: konowaluk@gmial.com Website: http://www.pswbp.pl

Anna Klim-Klimaszewska
PhD, Pope John Paul II State School of Higher Education in Biala Podlaska, Faculty of Humanities and Social Sciences, Department of Education, ul. Sidorska 95/97, 21-500 Biała Podlaska, Poland. E-mail: stnazaruk@poczta.onet.pl;

Website: http://www.pswbp.pl

PhD, Pope John Paul II State School of Higher Education in Biala Podlaska, Faculty of Humanities and Social Sciences, Department of Education, ul. Sidorska 95/97, 21-500 Biała Podlaska, Poland. E-mail: awaszczuk@op.pl Website: http:// www.pswbp.pl

PhD, Pope John Paul II State School of Higher Education in Biala Podlaska, Faculty of Humanities and Social Sciences, Department of Education, ul. Sidorska 95/97, 21-500 Biała Podlaska, Poland. E-mail: joanna44@o2.pl

Website: http:// www.pswbp.pl
PhD, Professor, Head of the Department of Teacher Education, University of Natural Sciences and Humanities in Siedlce, Faculty of Humanities, Institute of Education, ul. Żytnia 39, 08-110 Siedlce, Poland.

E-mail: anna.klim-klimaszewska@uph.edu.pl,klimanius@interia.pl Website: http://www.kd.ip.uph.edu.pl 